\title{
Regulated Emissions from Biodiesel Tested in Heavy-Duty Engines Meeting 2004 Emission Standards
}

\author{
Robert L. McCormick, Christopher J. Tennant, R. Robert Hayes, Stuart Black, John Ireland, \\ Tom McDaniel, Aaron Williams, Mike Frailey \\ National Renewable Energy Laboratory-U.S. Department of Energy
}

Christopher A. Sharp

Southwest Research Institute

Copyright () 2005 SAE International

\begin{abstract}
Biodiesel produced from soybean oil, canola oil, yellow grease, and beef tallow was tested in two heavy-duty engines. The biodiesels were tested neat and as $20 \%$ by volume blends with a $15 \mathrm{ppm}$ sulfur petroleumderived diesel fuel. The test engines were the following: 2002 Cummins ISB and 2003 DDC Series 60. Both engines met the 2004 U.S. emission standard of 2.5 $\mathrm{g} / \mathrm{bhp}-\mathrm{h} \mathrm{NO}+\mathrm{HC}(3.35 \mathrm{~g} / \mathrm{kW}-\mathrm{h})$ and utilized exhaust gas recirculation (EGR). All emission tests employed the heavy-duty transient procedure as specified in the U.S. Code of Federal Regulations. Reduction in PM emissions and increase in $\mathrm{NO}_{x}$ emissions were observed for all biodiesels in all engines, confirming observations made in older engines. On average PM was reduced by $25 \%$ and $\mathrm{NO}_{x}$ increased by $3 \%$ for the two engines tested for a variety of B20 blends. These changes are slightly larger in magnitude, but in the same range as observed in older engines. The cetane improver 2-ethyl hexyl nitrate was shown to have no measurable effect on $\mathrm{NO}_{x}$ emissions from B20 in these engines, in contrast to observations reported for older engines. The effect of intake air humidity on $\mathrm{NO}_{x}$ emissions from the Cummins ISB was quantified. The CFR $\mathrm{NO}_{x}$ /humidity correction factor was shown to be valid for an engine equipped with EGR, operating at $1700 \mathrm{~m}$ above sea level, and operating on conventional or biodiesel.
\end{abstract}

\section{INTRODUCTION}

Biodiesel is an oxygenated fuel or blending component made from vegetable oils, waste cooking oil, or animal fats by reaction of the triglyceride fats with methanol to form methyl esters via transesterification. Life cycle analysis indicates that biodiesel is highly renewable and its use, therefore, produces real reductions in petroleum consumption and carbon dioxide emissions [1]. Biodiesel is well known to cause a reduction in particulate matter (PM) emissions and to slightly increase oxides of nitrogen $\left(\mathrm{NO}_{\mathrm{x}}\right)$ emissions in most engines relative to petroleum diesel $[2,3]$.

The United States Environmental Protection Agency (EPA) produced a review of published biodiesel emissions data for heavy-duty engines. The results for $\mathrm{NO}_{\mathrm{x}}, \mathrm{PM}$, carbon monoxide (CO), and total hydrocarbons $(\mathrm{HC})$ are summarized in Figure 1, taken from that report [3]. The chart shows that, on average, substantial reductions in $\mathrm{PM}, \mathrm{CO}$, and $\mathrm{HC}$ can be obtained through use of biodiesel. However there is also an increase in $\mathrm{NO}_{x}$ emissions, by approximately $2 \%$ for B20 (20\% biodiesel by volume) blends and $10 \%$ for neat biodiesel (B100), on average. Engine model year and technology exhibited a large influence on $\mathrm{NO}_{x}$ emissions with the change in $\mathrm{NO}_{x}$ for $\mathrm{B} 20$ ranging from roughly $+8 \%$ to $-6 \%$, but averaging $+2 \%$. The $\mathrm{NO}_{x}$ increase may limit the use of biodiesel in non-attainment areas and is therefore a significant barrier to market expansion for this new fuel. Notably the studies reviewed by EPA did not include engines that meet the U.S. 2004 on-road standard of $2.5 \mathrm{~g} / \mathrm{bhp}-\mathrm{h} \mathrm{NO}+\mathrm{HC}$ (3.35 g/kW-h).

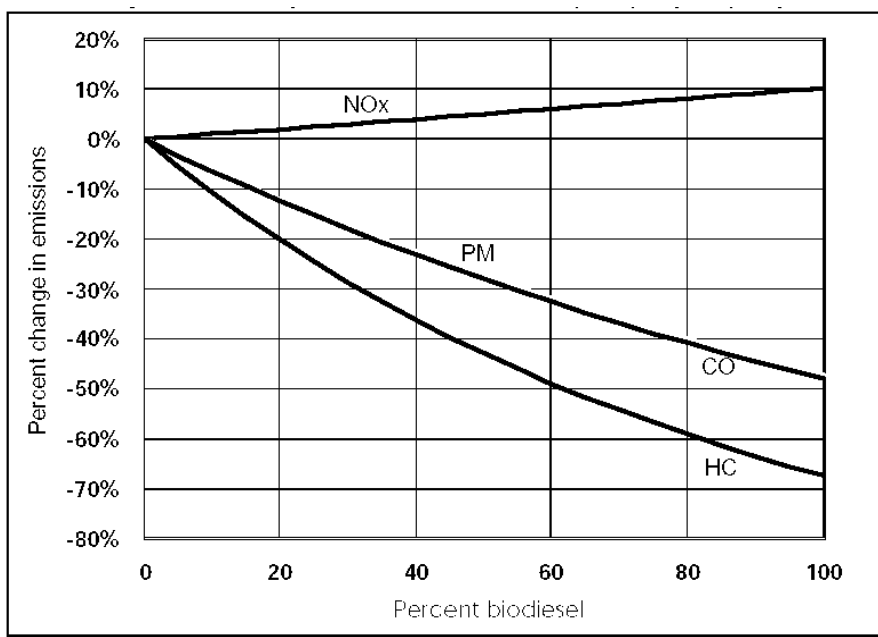

Figure 1. Summary of United States EPA evaluation of biodiesel impacts on pollutant emissions for heavy-duty engines (note PM and CO curves overlap). 
In this study biodiesel from several sources was tested in two engines meeting the 2004 U.S. heavy-duty emission requirements using the heavy-duty transient test. Neat biodiesels as well as various blends were tested in a 2002 Cummins ISB. Twenty percent biodiesel blends (B20) were tested in a 2003 DDC Series 60. Earlier work in a 1991 engine demonstrated that B20 $\mathrm{NO}_{\mathrm{x}}$ emissions could be lowered to a level equivalent to that of conventional diesel by blending of several thousand ppm of 2-ethyl hexyl nitrate (EHN) [4]. The use of $\mathrm{EHN}$ for $\mathrm{NO}_{\mathrm{x}}$ reduction was also investigated in this study.

\section{METHODS}

\section{FUELS AND FUEL PROPERTY MEASUREMENTS}

The baseline diesel fuel used both for comparison to the biodiesel fuels and as the diesel blend stock is a $15 \mathrm{ppm}$ sulfur fuel manufactured by BP and commonly referred to as BP15. Biodiesels meeting the ASTM D6751 specification were acquired from various sources. Biodiesels from the following feedstocks were tested: soybean oil, canola oil, yellow grease, and beef tallow. Two separate batches of soy biodiesel were used at different points in the study as noted in the results section. Appendix A-1 presents important property data for these fuels. Biodiesel blends (primarily B20) were prepared gravimetrically to achieve specific volume percentages. Cetane number for the B20 blends is reported in Appendix A-2. Cetane number results were acquired using both D613 (engine test) and D6890 (derived cetane number from constant volume combustion experiment), there is close agreement in cases were data from both methods are available. Additionally, a B20 soy-biodiesel blend with 2-ethyl hexyl nitrate added at four or five thousand ppm, and targeted at increasing cetane number by 10 units, was tested in both engines.

\section{EMISSIONS TESTING}

All emission tests were conducted according to CFR Title 40 Part 86 Subpart N, the heavy-duty transient. The baseline fuel engine-torque curve was used to generate the transient test for all fuels. Repeat hot-start tests were performed on each fuel with control test runs on the reference fuel included on every test day to minimize the effect of day-to-day variability on the fuel comparisons.

The Cummins ISB engine was tested at NREL's ReFUEL laboratory and the Detroit Diesel Corporation (DDC) Series 60 was tested at SwRI. Both laboratories employed the full-scale dilution tunnel method with constant volume sampling for mass flow measurement. Gaseous emissions of $\mathrm{NO}_{\mathrm{x}}, \mathrm{HC}, \mathrm{CO}$ and $\mathrm{CO}_{2}$ were continuously sampled and analyzed using standard methods. PM emissions were collected on filters using double-dilution with a secondary dilution ratio of roughly 2-to-1. A class 1000 clean room with precise environmental controls was used for all filter handling, conditioning and weighing at ReFUEL. PM filter handling was performed in HEPA filtered temperature and humidity controlled chambers at SwRI. Intake and dilution tunnel air were conditioned for humidity and temperature, and then passed through a HEPA filter to eliminate background particulate matter. All emissions data were corrected for background, analyzer span and humidity in accordance with CFR recommendations. The $\mathrm{NO}_{\mathrm{x}}$ humidity correction factor (40 CFR 86.134294(d)(8)(iii)) was applied to the real time data to correct to an absolute humidity of 75 grains/lb. Experiments were performed to confirm the validity of the CFR humidity correction factor for petroleum-based diesel and neat biodiesel in the Cummins ISB at Denver's altitude $(1700 \mathrm{~m})$, as described in the Results.

Properties of the test engines are shown in Table 1. Both engines are direct injection, inter-cooled with cooled high-pressure EGR, employ a variable geometry turbocharger, and electronic control. The 2002 Cummins ISB employs a high-pressure common rail fuel injection while the 2003 DDC Series 60 features highpressure electronic unit injectors (EUI).

Table 1. Test engine specifications.

\begin{tabular}{l|c|c}
\hline & Cummins ISB & DDC Series 60 \\
\hline Serial Number & 56993170 & $06 \mathrm{R} 0773118$ \\
\hline Displacement, L & 5.9 & 14 \\
\hline Cylinders & 6 & 6 \\
\hline Rated Power, kW & $224 @ 2500 \mathrm{rpm}$ & $373 @ 1800 \mathrm{rpm}$ \\
\hline Rated Torque & $895 \mathrm{~N}-\mathrm{m} @$ & $2237 \mathrm{~N}-\mathrm{m} @$ \\
& $1600 \mathrm{rpm}$ & $1200 \mathrm{rpm}$ \\
\hline Bore x Stroke & $10.2 \times 12 \mathrm{~cm}$ & $13.3 \times 16.8 \mathrm{~cm}$ \\
\hline Compression Ratio & $16.5: 1$ & $16.0: 1$ \\
\hline Fuel System & Common Rail & EUI \\
\hline $\begin{array}{l}\text { Intake Restriction, } \\
\text { kPa }\end{array}$ & 4.47 & 3.97 \\
\hline Exhaust & & \\
Backpressure, $\mathrm{kPa}$ & 7.95 & 8.10 \\
\hline
\end{tabular}

\section{RESULTS}

Emission results for both engines and all fuels are summarized as percent change in emissions in Figure 2. Biodiesel shows a trend towards reductions in $\mathrm{HC}$ and CO. However, for B20 and lower blends these changes are generally not statistically significant. This is in contrast to the results shown in Figure 1 where $\mathrm{CO}$ emission reductions closely tracked $\mathrm{PM}$ emission reductions and where $\mathrm{HC}$ emission reductions are large and measurable. At higher blend levels both $\mathrm{HC}$ and $\mathrm{CO}$ are reduced. The trends for $\mathrm{NO}_{\mathrm{x}}$ and $\mathrm{PM}$ shown in Figure 2 are similar to those in Figure 1, however changes in emissions are larger. $\mathrm{NO}_{\mathrm{x}}$ emissions increased in an approximately linear manner with blend level. For B20 and lower blend levels the PM reduction may exceed that predicted by a linear fit of the data.

Table 2 compares average percent change in emissions for B20 from the EPA study of 1997 and older engines [3] with those measured for the two engines tested here. 
The average change in $\mathrm{HC}$ for this study is not significantly different from zero and represents the error inherent in measuring the very low levels of total hydrocarbon emitted by modern diesel engines. CO emissions were reduced on average for the 2004 engines, but the percent reduction is less than for older engines. The $\mathrm{NO}_{\mathrm{x}}$ emission increase for B20 appears somewhat higher than observed in the older engines. However, both studies found a broad range of changes in $\mathrm{NO}_{\mathrm{x}}$ and the results for the 2004 engines fall well within the range observed in the EPA study. The large variability in percent change in $\mathrm{NO}_{\mathrm{x}}$ is caused by the use of biodiesels from a variety of feedstocks, as discussed below. PM reductions for the two engines are on average more than twice as large as observed in older engines. Note that the effect of biodiesel on emissions was shown to be sensitive to base diesel properties [3]. The EPA study results listed in Table 2 are averages for a wide range of base fuels.
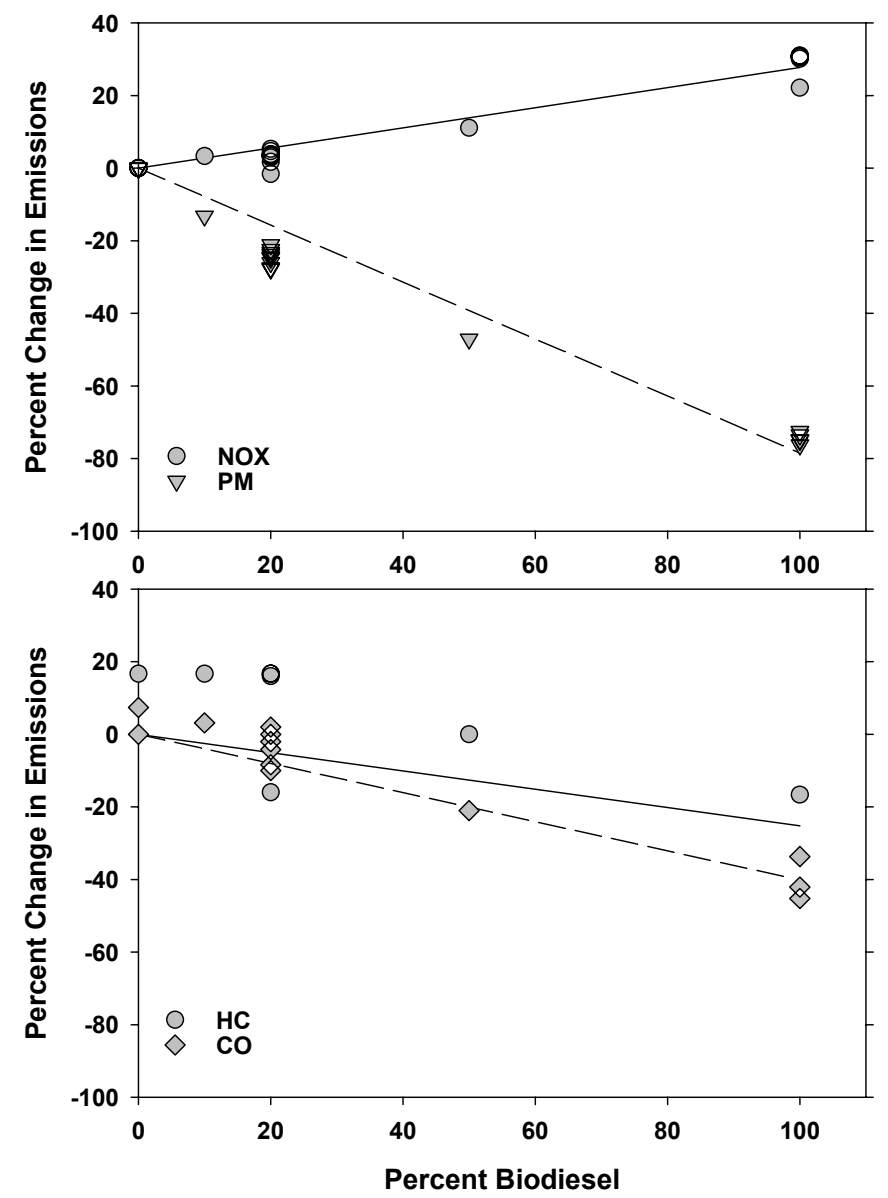

Figure 2. Effect of biodiesel on changes in pollutant emissions for all fuels and both engines.

Table 2. Average change in emissions for B20, 95\% confidence interval shown for results from this study.

\begin{tabular}{lcc}
\hline & EPA 2002 [3] & This study \\
\hline $\mathrm{HC}$ & -21.1 & $+3 \pm 8$ \\
$\mathrm{CO}$ & -11.0 & $-4 \pm 3.3$ \\
$\mathrm{NO}_{\mathrm{x}}$ & +2.0 & $+3 \pm 1.5$ \\
$\mathrm{PM}$ & -10.1 & $-25 \pm 1.7$ \\
\hline
\end{tabular}

\section{CUMMINS ISB}

Average transient test results for each fuel tested in the Cummins ISB are tabulated in Appendix A-3. These data represent results for three or more hot-start transient tests. Work with this engine includes tests of all five biodiesels as B100 and B20. Additionally, soy biodiesel was tested as B10 and B50, and as B20 with 4000 ppm of EHN. Both Soy 1 and Soy 2 were used at different stages of the study. Comparison of the results for these two fuels as B100 or B20 shows no significant difference in emissions performance.

Figures 3 and 4 show $\mathrm{NO}_{\mathrm{x}}$ and $\mathrm{PM}$ results for testing of B100 and B20, respectively, in the ISB. Both B100 and B20 produce reductions in PM that are independent of biodiesel feedstock. $\mathrm{NO}_{\mathrm{x}}$ emissions increase significantly for $\mathrm{B} 100$ and the increase varies with biodiesel feedstock. Note that B100 has approximately $10 \%$ lower energy content per volume than conventional diesel resulting in about 3\% lower cycle work. This effect is insignificant for $\mathrm{B} 20$. For B20 the $\mathrm{NO}_{\mathrm{x}}$ increase is evident for all biodiesels but the effect of feedstock is much less pronounced.

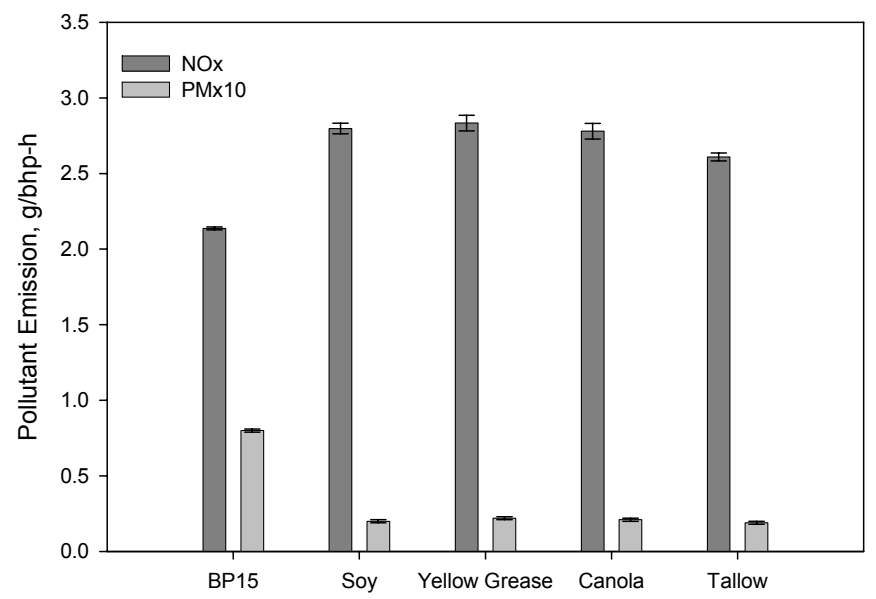

Figure 3. $\mathrm{NO}_{\mathrm{x}}$ and $\mathrm{PM}$ emission results for testing of B100 fuels in the Cummins ISB.

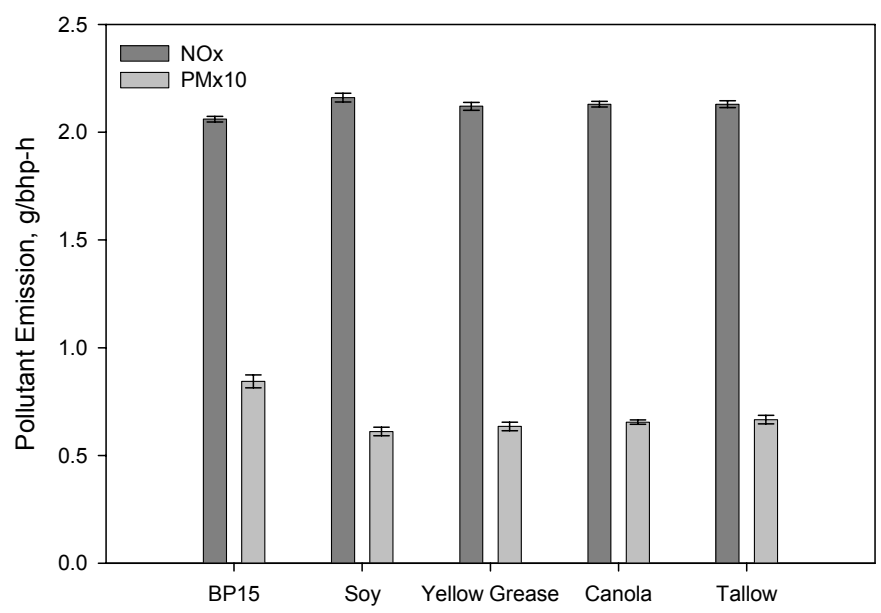

Figure 4. $\mathrm{NO}_{\mathrm{x}}$ and $\mathrm{PM}$ emission results for testing of B20 fuels in the Cummins ISB. 


\section{DDC SERIES 60}

Average transient test results are tabulated in Appendix A-4. The data in this table represent an average of three hot-start tests. This engine was tested with B20 blends using biodiesel made from soy (Soy 1), yellow grease, and tallow. A B20 was prepared using $10 \%$ soy and $10 \%$ tallow to investigate the potential for blending of more saturated biodiesel as a $\mathrm{NO}_{x}$ reduction strategy. Also, a soy biodiesel was tested as B20 with 5000 ppm of EHN.

$\mathrm{NO}_{x}$ and PM results are shown in Figure 5. A significant reduction in $\mathrm{PM}$ emissions is observed independent of feedstock. $\mathrm{NO}_{x}$ emissions increased significantly for soy B20, but were statistically unchanged for the yellow grease biodiesel and increased only marginally for beef tallow. In an attempt to lower $\mathrm{NO}_{\mathrm{x}}$ emissions, fuel was prepared from $10 \%$ soy, $10 \%$ tallow, and $80 \%$ baseline diesel. Testing of this fuel shows a small but statistically insignificant reduction in $\mathrm{NO}_{x}$ as compared to the soy only B20 tests.

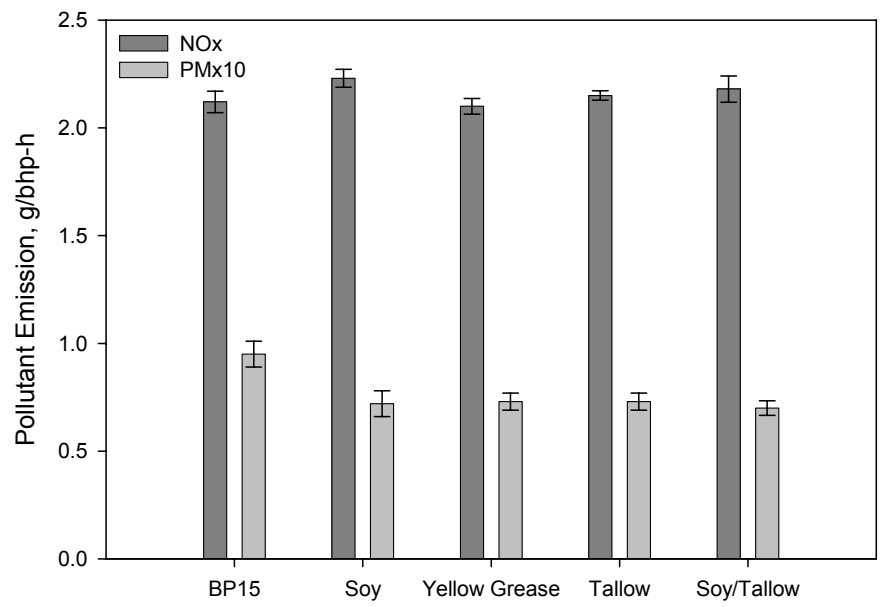

Figure 5. $\mathrm{NO}_{\mathrm{x}}$ and $\mathrm{PM}$ emission results for testing of B20 fuels in the DDC Series 60.

\section{EFFECT OF CETANE IMPROVER}

Earlier work has shown that cetane-increasing additives, specifically $\mathrm{EHN}$ and di-tert butyl peroxide, are effective for reducing $\mathrm{NO}_{\mathrm{x}}$ emissions from B20 blends in older engines $[4,5,6]$. McCormick and coworkers tested these additives at different blend levels and showed that a treat rate of approximately $5000 \mathrm{ppm}$ produces a $\mathrm{NO}_{x}$ equivalent B20 when testing in a 1991 DDC Series 60 engine. This EHN treat rate typically produces an increase of ten cetane units. Engines meeting the 2.5 $\mathrm{g} / \mathrm{bhp}-\mathrm{h} \mathrm{NO} \mathrm{NO}_{\mathrm{x}}+\mathrm{HC}$ standard such as those tested here have much more highly retarded injection timing and are therefore much less sensitive to the effect of cetane number [7], thus it was of interest to examine the effect of cetane improvers on $\mathrm{NO}_{\mathrm{x}}$ emissions for these engines.

Results of testing with EHN are shown in Figures 6 and 7 for the ISB and Series 60, respectively. The ISB was tested with B20+4000 ppm of EHN producing a cetane number increase of 8 units. The Series 60 was tested with B20 +5000 ppm of EHN producing a cetane number increase of 10 units (see Appendix A-2). In both cases addition of EHN had no measurable (i.e. statistically significant) effect on $\mathrm{NO}_{\mathrm{x}}$, confirming the cetane insensitivity of $\mathrm{NO}_{x}$ emissions in engines meeting this $\mathrm{NO}_{\mathrm{x}}$ emission standard, as has been noted by others [7]. Additionally, the cetane improver had no impact on emissions of other pollutants either.

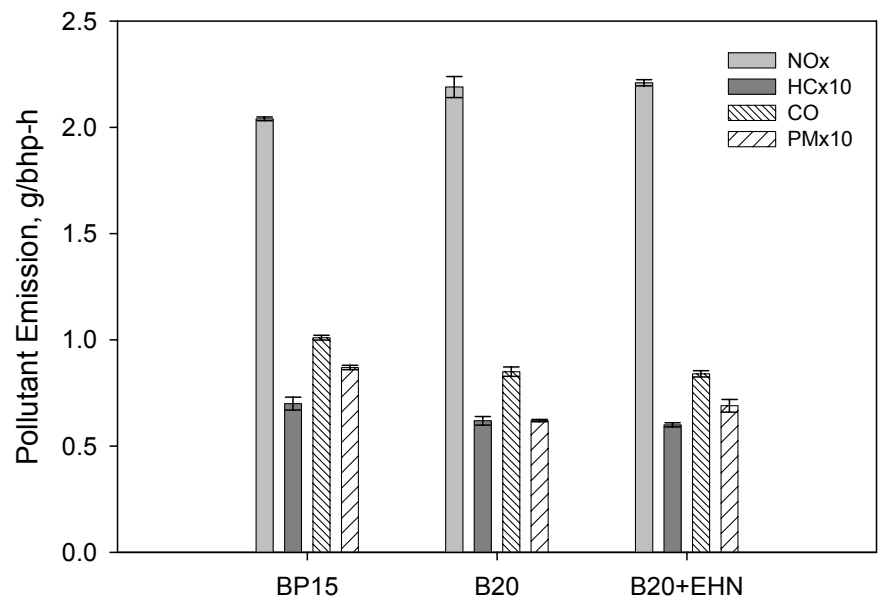

Figure 6. Results for testing of soy B20 containing 4000 ppm of EHN in the Cummins ISB engine.

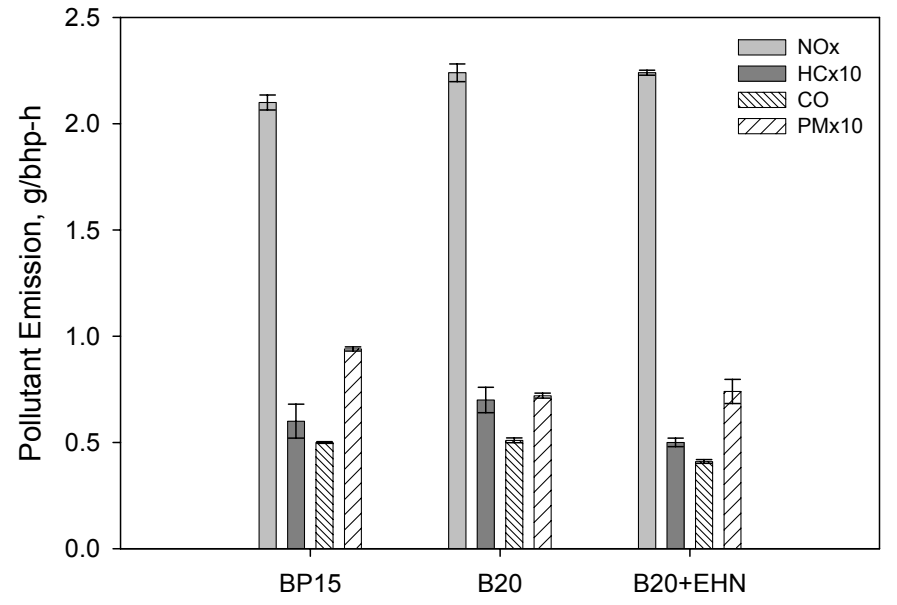

Figure 7. Results for testing of soy B20 containing 5000 ppm of EHN in the DDC Series 60 engine.

\section{EFFECT OF INTAKE AIR HUMIDITY}

Tests were conducted to demonstrate the influence that intake air humidity has on $\mathrm{NO}_{x}$ emissions for the Cummins ISB engine. Figures 8 and 9 show the relationship between humidity and $\mathrm{NO}_{\mathrm{x}}$ for both baseline diesel and B100 Soy 2. The uncorrected data show a nearly linear relationship between intake air humidity and $\mathrm{NO}_{x}$ levels. The CFR NO , humidity correction factor was applied to correct all data to an inlet humidity of 75 grains/lb. This yielded $\mathrm{NO}_{x}$ averages of $2.10 \mathrm{~g} / \mathrm{bhp}-\mathrm{hr}$ for baseline diesel and $2.75 \mathrm{~g} / \mathrm{bhp}$-hr for B100. This is consistent with results from previous testing; confirming the validity of applying the CFR correction factor to an EGR engine, fueled with either ultra-low sulfur diesel or biodiesel, and operated at altitude $(1700 \mathrm{~m})$. 


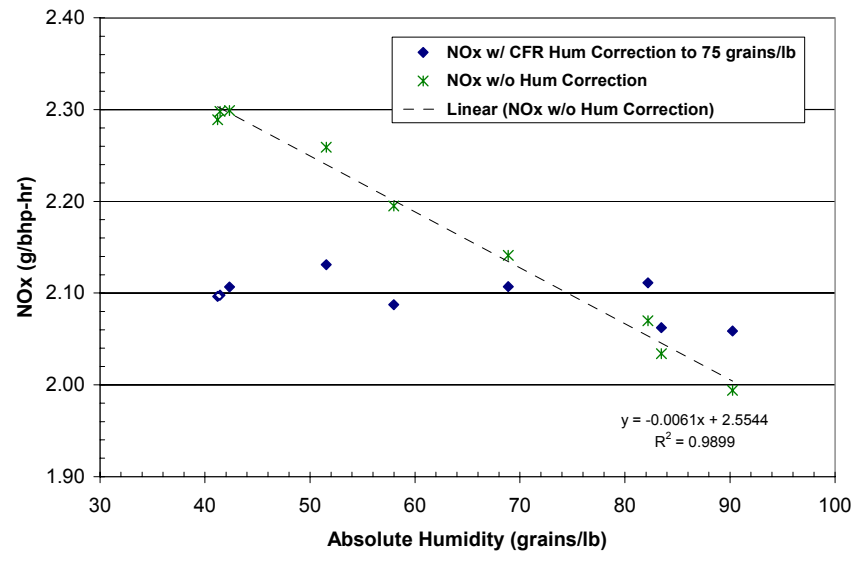

Figure 8. Effect of intake air humidity and application of the $\mathrm{NO}_{\mathrm{x}}$ correction factor on emissions from baseline diesel fuel.

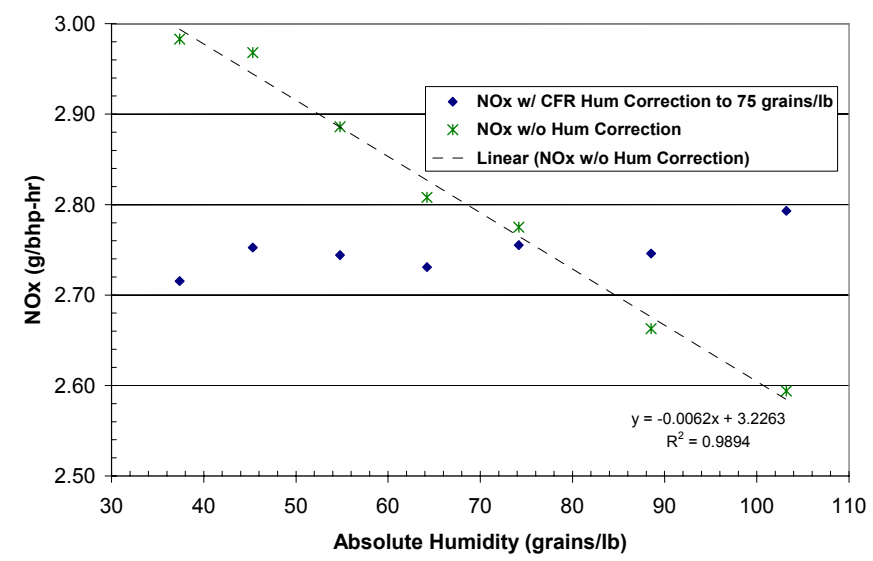

Figure 9. Effect of intake air humidity and application of the $\mathrm{NO}_{\mathrm{x}}$ correction factor on emissions from B100 Soy 2 .

\section{DISCUSSION}

Considerable effort has been devoted to determining the reason that biodiesel increases $\mathrm{NO}_{x}$ emissions. One theory holds that the cause of the $\mathrm{NO}_{x}$ increase is a shift in fuel injection timing caused by different mechanical properties of biodiesel $[8,9]$. Because of the higher bulk modulus of compressibility (or speed of sound) for biodiesel there is a more rapid transfer of the fuel pump pressure wave to the injector needle, resulting in earlier needle lift or effectively a small advance in injection timing. Sybist and Boehman have recently examined this effect in more detail [10]. They found that soy B100 produces a $1^{\circ}$ advance in injection timing but a nearly $4^{\circ}$ advance in the start of combustion. This bulk modulus effect appears to be applicable, at least theoretically, to pump-line nozzle and unit injection systems, but would not appear to be relevant to high-pressure common rail systems where "rapid transfer of a pressure wave" does not occur.

It was observed in earlier studies on a 1991 engine equipped with electronic unit injectors that biodiesel produced from more saturated feedstocks (lower iodine number) such as animal fats produced lower $\mathrm{NO}_{x}$ emissions [1]. The bulk modulus of compressibility was also shown to be correlated with iodine value and to be lower for biodiesel produced from more highly saturated feedstocks [8], as shown in Figure 10. Thus, in the discussion that follows iodine number will be used as a surrogate for bulk modulus of compressibility.

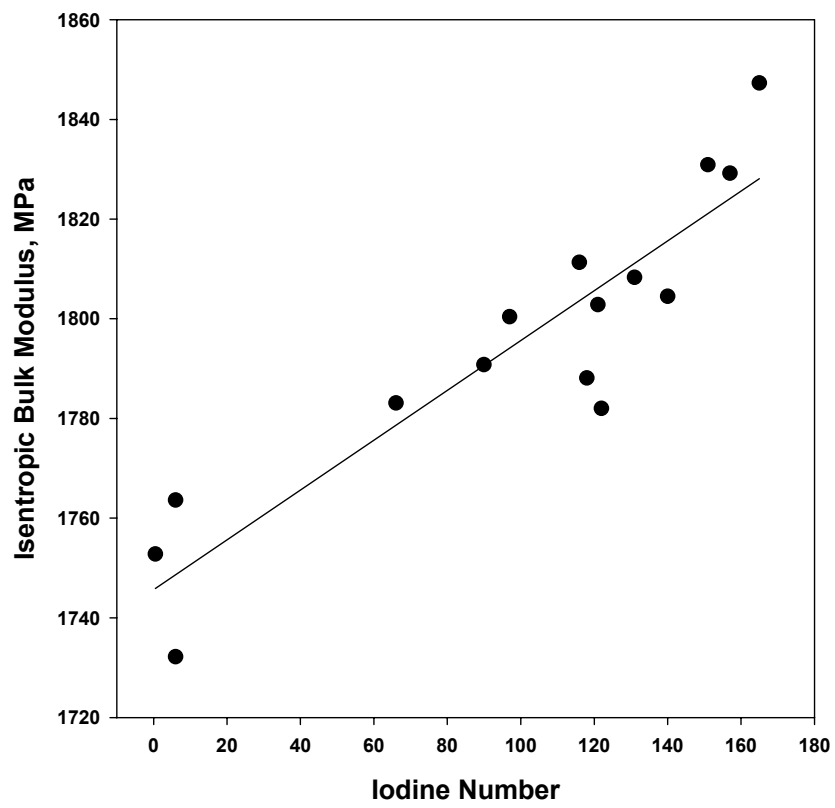

Figure 10. Relationship between isentropic bulk modulus of compressibility and iodine number for a range of biodiesel fuels $\left(r^{2}=0.83\right)$, data taken from reference 8 for $40^{\circ} \mathrm{C}$ and $20 \mathrm{MPa}$.

Figure 11 shows results from this earlier study, along with results of B100 testing in the ISB engine, in terms of brake specific $\mathrm{NO}_{x}$ emissions as a function of fuel iodine value (a measure of the degree of saturation or number of double bonds per mass of sample). For the 1991 engine data the slope of the regression line is significant at greater than $99 \%$ confidence. For the ISB engine the slope is also statistically significant, although the effect is much smaller than observed in the older engine. This smaller effect of fuel saturation suggests that the bulk modulus effect discussed above is less important for common rail injection systems.

B20 blends were tested in engines with both common rail and electronic unit injection systems. While the $\mathrm{NO}_{x}$ increase is much smaller for B20 blends, making feedstock effects more difficult to observe, we have examined these data in terms of iodine number in Figure 12. A significant effect of biodiesel iodine value on $\mathrm{NO}_{x}$ was observed for B20 blends in the 1991 engine [11]. $\mathrm{NO}_{x}$ emissions from the newer engines are less than half the emissions from the 1991 engine, and while error bars (one standard deviation) are typically $2 \%$ to $3 \%$ of the mean, it is not possible to observe an effect for iodine value with a high degree of statistical significance for blends. Nevertheless, for the most unsaturated fuels (highest iodine value) $\mathrm{NO}_{x}$ emissions are significantly higher for the electronic unit injection engine (Series 60) than for the common rail engine. Thus it seems possible that a saturation (or bulk modulus) effect is occurring for 
the unit injection system but is too small to be accurately quantified for B20 blends. Testing with a series of B100 fuels might reveal a significant effect given the much higher levels of emissions.

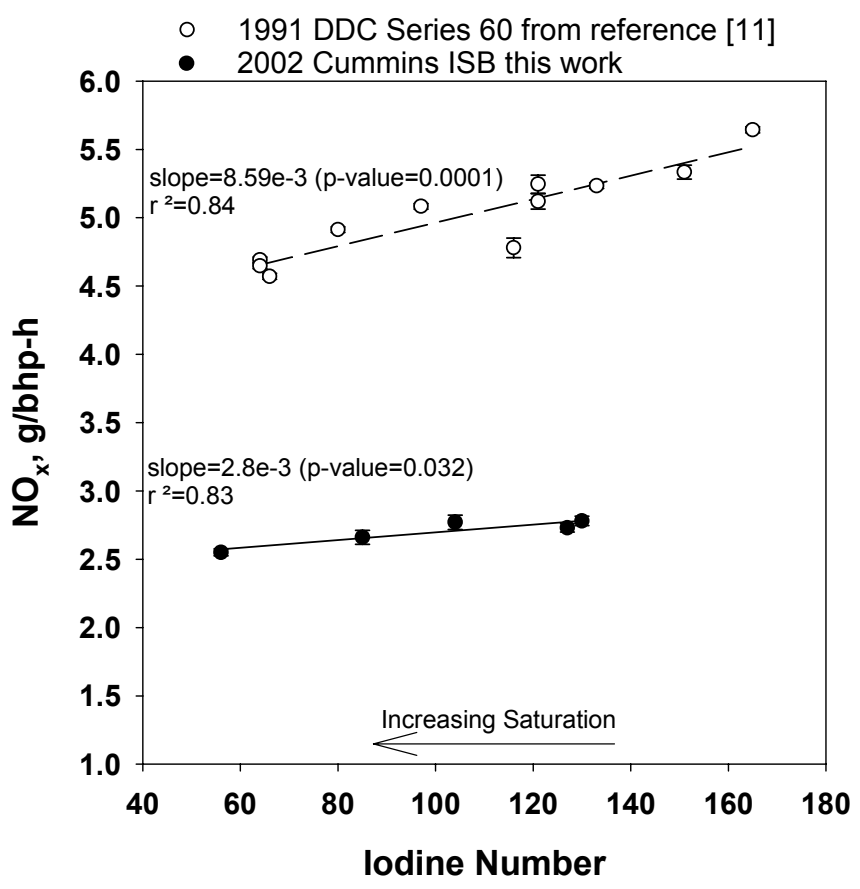

Figure 11. Effect of biodiesel degree of saturation on $\mathrm{B} 100 \mathrm{NO}_{\mathrm{x}}$ emissions (iodine number via ASTM D1959).

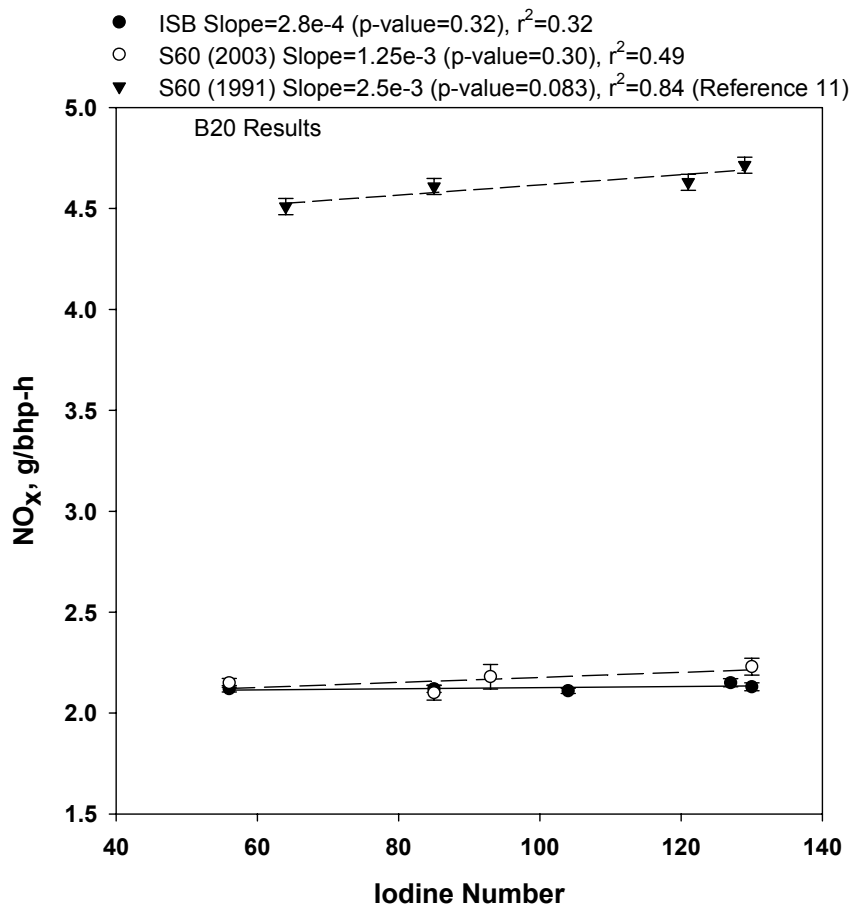

Figure 12. Effect of biodiesel degree of saturation on B20 NO emissions (iodine number via ASTM D1959).

Another important property difference between conventional diesel and biodiesel is energy content, with B100 typically having about $10 \%$ lower heat of combustion per volume. The modern engines tested in the present study have complex and highly sophisticated controls based on measurement of fuel flow rate, exhaust and EGR loop temperature, EGR flow rate, and other factors. The values of these measured parameters may change significantly when burning a lower energy content fuel such as B100, altering the way the engine operates in unanticipated ways.

\section{CONCLUSIONS}

1. In engines meeting the 2004 emission standards $\mathrm{NO}_{x}$ emissions increase by about 3\% for B20. This is not statistically different from what is observed in testing of older engines.

2. PM emissions decrease by a significantly larger amount $(25 \%$ versus $10 \%)$, on average, than was observed in older engines.

3. The biodiesel degree of saturation, and by implication bulk modulus of compressibility, had a small effect on $\mathrm{NO}_{\mathrm{x}}$ for a common rail injection system (B100), in comparison to the much larger effect observed in older engines. For B20 blends no significant effect of biodiesel degree of saturation on $\mathrm{NO}_{\mathrm{x}}$ was observed.

4. Because the results show a significant increase in $\mathrm{NO}_{x}$ for both electronic unit injection and highpressure common rail systems, the higher fuel bulk modulus for biodiesel is probably not the exclusive cause of the $\mathrm{NO}_{x}$ increase.

5. The addition of a cetane increasing additive, 2-ethyl hexyl nitrate, had no effect on $\mathrm{NO}_{\mathrm{x}}$ in either engine.

\section{ACKNOWLEDGMENTS}

The authors wish to thank Cummins, Inc. for loan of the ISB engine and technical assistance, West Central Soy for supplying the soy-biodiesel, Griffin Industries for supplying the yellow grease and beef tallow-derived biodiesels, Natural Resources Canada for supplying the canola-derived biodiesel, and Lubrizol Corporation for supplying the EHN fuel additive. The FreedomCAR and Vehicle Technologies Program, Fuels Technologies Subprogram of the U.S. Department of Energy supported this work.

\section{REFERENCES}

1. Sheehan J., Camobreco V., Duffield J., Graboski M. and Shapouri H. "An Overview of Biodiesel and Petroleum Diesel Life Cycles", National Renewable Energy Laboratory, NREL/TP-580-24772, May 1998.

2. Graboski, M.S., McCormick, R.L. "Combustion of Fat and Vegetable Oil Derived Fuels in Diesel Engines" Progress in Energy and Combustion Science, 24, 125 (1998) and references therein.

3. United States Environmental Protection Agency. 2002. "A Comprehensive Analysis of Biodiesel 
Impacts on Exhaust Emissions", Draft Technical Report, EPA420-P-02-001.

4. McCormick, R.L., Alvarez, J.R., Graboski, M.S., Tyson, K.S., Vertin, K. "Fuel Additive and Blending Approaches to Reducing $\mathrm{NO}_{x}$ Emissions from Biodiesel" SAE Technical Paper No. 2002-01-1658 (2002).

5. Sharp, C.A. "Transient Emissions Testing of Biodiesel in a DDC 6V-92TA Engine" Final Report to National Biodiesel Board, SWRI, Oct. 1994.

6. Sharp, C.A. "Transient Emissions Testing of Biodiesel and Other Additives in a DDC Series 60 Engine" Final Report to National Biodiesel Board, SWRI, Dec. 1994.

7. Matheaus, A.C., Neely, G.D., Ryan, T.W., Sobotowski, R.A., Wall, J.C., Hobbs, C.H., Passavant, G.W., Bond, T.J. "EPA HDEWG Program-Engine Tests Results" SAE Technical Paper No. 2000-01-1858 (2000).

8. Tat, M.E. and van Gerpen, J.J. "Measurement of Biodiesel Speed of Sound and Its Impact on Injection Timing", National Renewable Energy Laboratory, NREL/SR-510-31462, February 2003.

9. Monyem, A., van Gerpen, J.J. and Canakci, M. "The Effect Of Timing And Oxidation On Emissions From Biodiesel-Fueled Engines" Trans. of the Am. Soc. of Agricultural Engineers 44, 35 (2001).

10. Sybist, J.P. and Boehman, A.L. "Behavior Of A Diesel Injection System With Biodiesel Fuel" SAE Technical Paper No. 2003-01-1039 (2003)

11. McCormick, R.L., Graboski, M.S., Alleman, T.L., Herring, A.M. "Impact of Biodiesel Source Material and Chemical Structure on Emissions of Criteria Pollutants from a Heavy-Duty Engine" Environ. Sci. Technol. 35, 1742 (2001).

\section{CONTACT}

Robert L. McCormick can be contacted at:

Center for Transportation Technologies and Systems National Renewable Energy Laboratory

1617 Cole Blvd., MS 1633

Golden, CO 80401-3393

USA

303-275-4432

robert_mccormick@nrel.gov

\section{ACRONYMS AND ABBREVIATIONS}

ASTM - ASTM International, originally known as the American Society for Testing and Materials

BSFC - Brake specific fuel consumption

BP - BP p.I.c. and its subsidiaries and affiliates, formerly known as British Petroleum

Bxx - A volumetric blend of $x x \%$ biodiesel in conventional diesel

CFR - United States Code of Federal Regulations

$\mathrm{CO}$ - Carbon monoxide
DDC - Detroit Diesel Corporation

EGR - Exhaust gas recirculation

$\mathrm{EHN}$ - 2-ethylhexyl nitrate cetane improver additive

EPA - United States Environmental Protection Agency

EUI - electronic unit injector

$\mathrm{HC}$ - total hydrocarbon

HEPA - high efficiency particulate air

$\mathrm{NO}_{x}-$ oxides of nitrogen ( $\mathrm{NO}$ and $\mathrm{NO}_{2}$ )

NREL - National Renewable Energy Laboratory

PM - particulate matter

S60 - DDC Series 60 engine

SwRI - Southwest Research Institute

$Y G$ - yellow grease 
Table A-1. Results of fuel property testing for baseline diesel and B100.

\begin{tabular}{|c|c|c|c|c|c|c|c|c|}
\hline Property & Method & Units & $\begin{array}{c}\text { Baseline } \\
\text { Diesel }\end{array}$ & $\begin{array}{c}\text { Soy Biodiesel } \\
\text { Batch } 1\end{array}$ & $\begin{array}{l}\text { Soy Biodiesel } \\
\text { Batch } 2\end{array}$ & $\begin{array}{c}\text { Canola } \\
\text { Biodiesel }\end{array}$ & $\begin{array}{c}\text { Yellow Grease } \\
\text { Biodiesel }\end{array}$ & $\begin{array}{c}\text { Beef Tallow } \\
\text { Biodiesel }\end{array}$ \\
\hline Cetane Number & D613 & & 51 & 53 & 52 & 58 & 56 & 65 \\
\hline Kinematic Viscosity 40C & D445 & $\mathrm{mm} 2 / \mathrm{s}$ & 2.5 & 4.12 & 4.07 & 3.53 & 4.61 & 4.71 \\
\hline Cloud Point & D2500 & ${ }^{\circ} \mathrm{C}$ & -12 & -2 & 1 & -2 & 8 & 14 \\
\hline Flash Point & D93 & ${ }^{\circ} \mathrm{C}$ & 64 & 161 & 115 & 150 & 165 & 159 \\
\hline Total Sulfur & D5453 & ppm & 13 & 1 & 0 & 1 & 5 & 8 \\
\hline Ash Content & D482 & wt\% & 0.000 & -- & -- & -- & -- & -- \\
\hline Sulfated Ash & D874 & wt $\%$ & -- & 0.001 & 0.001 & 0.000 & 0.000 & 0.000 \\
\hline Specific Gravity & D4052 & & 0.8371 & 0.8823 & 0.8838 & 0.8816 & 0.8793 & 0.8754 \\
\hline Carbon Residue & D524 & $w t \%$ & 0.04 & $<0.010$ & 0.015 & $<0.010$ & $<0.010$ & $<0.010$ \\
\hline Corrosion, Copper strip & D130 & & $1 \mathrm{~A}$ & $1 \mathrm{~A}$ & $1 \mathrm{~A}$ & $1 \mathrm{~A}$ & $1 \mathrm{~A}$ & $1 \mathrm{~A}$ \\
\hline Water and Sediment & D2709 & vol\% & 0 & 0 & 0 & 0 & 0 & 0 \\
\hline Acid Number & D664 & $\mathrm{mgKOH} / \mathrm{g}$ & -- & 0.34 & 0.62 & 0.16 & 0.52 & 0.48 \\
\hline Carbon & D5291 & wt $\%$ & 86.04 & -- & -- & -- & -- & -- \\
\hline Hydrogen & D5291 & wt\% & 13.48 & -- & -- & -- & -- & -- \\
\hline Phosphorus & D4951 & wt $\%$ & -- & 0.0007 & 0.0000 & 0.0000 & 0.0000 & 0.0004 \\
\hline Aromatics & D1319 & $\%$ vol & 29 & -- & -- & -- & -- & -- \\
\hline Free Glycerin & D6584 & $w t \%$ & -- & 0.001 & 0.002 & 0.010 & 0.005 & 0.006 \\
\hline Total Glycerin & D6584 & wt\% & -- & 0.022 & 0.166 & 0.176 & 0.102 & 0.058 \\
\hline Distillation T90 & D86 & ${ }^{\circ} \mathrm{C}$ & 322 & 351 & 351 & 352 & 351 & 351 \\
\hline Iodine Value & D1959 & & -- & 130 & 127 & 104 & 85 & 56 \\
\hline
\end{tabular}

Biodiesel carbon residue measured on total sample rather than $10 \%$ bottoms, as required by ASTM D6751.

Table A-2. Cetane Number of B20 Blends

\begin{tabular}{lcc}
\hline \multicolumn{1}{c}{ Fuel } & $\begin{array}{c}\text { Cetane Number } \\
\text { D613 }\end{array}$ & $\begin{array}{c}\text { Cetane Number } \\
\text { D6890 }\end{array}$ \\
\hline B20 Soy 1 & 51 & 52 \\
B10 Soy 2 & -- & -- \\
B20 Soy 2 & -- & 49 \\
B50 Soy 2 & -- & 53 \\
B20 Yellow Grease & 54 & 53 \\
B20 Canola & -- & 55 \\
B20 Beef Tallow & 57 & 54 \\
B20 Soy/Tallow & 54 & -- \\
B20+4000 ppm EHN & -- & 60 \\
B20+5000 ppm EHN & 61 & -- \\
\hline
\end{tabular}


Table A-3. Hot-Start Transient Emission Test Results for the Cummins ISB Engine $(1 \mathrm{~g} / \mathrm{bhp}-\mathrm{h}=1.341 \mathrm{~kW}-\mathrm{h})$.

\begin{tabular}{|c|c|c|c|c|c|c|c|}
\hline \multirow{2}{*}{ Fuel } & & \multicolumn{4}{|c|}{ Transient Emissions, g/hp-hr } & \multirow{2}{*}{$\frac{\text { BSFC }}{\text { Ib/hp-hr }}$} & \multirow{2}{*}{$\begin{array}{l}\text { Work } \\
\mathrm{hp}-\mathrm{hr}\end{array}$} \\
\hline & & $\mathrm{HC}$ & $\mathrm{CO}$ & NOx & PM & & \\
\hline Baseline & Mean & 0.06 & 0.90 & 2.18 & 0.081 & 0.402 & 19.91 \\
\hline \multirow[t]{2}{*}{$5 / 13 / 2004$} & Std. Dev. & 0.002 & 0.007 & 0.010 & 0.001 & 0.000 & 0.030 \\
\hline & $\%$ COV & 4.0 & 0.8 & 0.5 & 1.0 & 0.1 & 0.2 \\
\hline YG B100 & Mean & 0.04 & 0.52 & 2.83 & 0.022 & 0.460 & 19.35 \\
\hline \multirow[t]{2}{*}{$5 / 13 / 2004$} & Std. Dev. & 0.002 & 0.006 & 0.051 & 0.001 & 0.001 & 0.005 \\
\hline & $\%$ COV & 4.5 & 1.2 & 1.8 & 4.6 & 0.2 & 0.0 \\
\hline Baseline & Mean & 0.06 & 0.95 & 2.15 & 0.078 & 0.406 & 19.92 \\
\hline \multirow[t]{2}{*}{$5 / 19 / 2004$} & Std. Dev. & 0.003 & 0.012 & 0.006 & 0.002 & 0.001 & 0.032 \\
\hline & $\%$ COV & 4.7 & 1.3 & 0.3 & 2.3 & 0.2 & 0.2 \\
\hline Canola B100 & Mean & 0.04 & 0.55 & 2.78 & 0.021 & 0.459 & 19.35 \\
\hline \multirow{2}{*}{$5 / 19 / 2004$} & Std. Dev. & 0.001 & 0.006 & 0.052 & 0.001 & 0.000 & 0.035 \\
\hline & $\%$ COV & 2.9 & 1.1 & 1.9 & 3.4 & 0.1 & 0.2 \\
\hline Baseline & Mean & 0.06 & 0.96 & 2.10 & 0.080 & 0.404 & 19.95 \\
\hline \multirow[t]{2}{*}{$5 / 20 / 2004$} & Std. Dev. & 0.001 & 0.021 & 0.040 & 0.002 & 0.000 & 0.012 \\
\hline & $\%$ COV & 1.3 & 2.2 & 1.9 & 2.4 & 0.1 & 0.1 \\
\hline Tallow B100 & Mean & 0.04 & 0.52 & 2.61 & 0.019 & 0.461 & 19.29 \\
\hline \multirow[t]{2}{*}{$5 / 20 / 2004$} & Std. Dev. & 0.002 & 0.013 & 0.026 & 0.000 & 0.000 & 0.028 \\
\hline & $\%$ COV & 4.8 & 2.6 & 1.0 & 1.7 & 0.0 & 0.1 \\
\hline Baseline & Mean & 0.06 & 0.97 & 2.12 & 0.083 & 0.405 & 19.92 \\
\hline \multirow[t]{2}{*}{$5 / 21 / 2004$} & Std. Dev. & 0.001 & 0.004 & 0.021 & 0.001 & 0.001 & 0.029 \\
\hline & $\%$ COV & 1.5 & 0.4 & 1.0 & 1.5 & 0.3 & 0.1 \\
\hline Soy 1 B100 & Mean & 0.04 & 0.55 & 2.80 & 0.020 & 0.462 & 19.31 \\
\hline \multirow[t]{2}{*}{$5 / 21 / 2004$} & Std. Dev. & 0.003 & 0.011 & 0.035 & 0.000 & 0.000 & 0.015 \\
\hline & $\%$ COV & 7.2 & 1.9 & 1.3 & 0.5 & 0.1 & 0.1 \\
\hline Baseline & Mean & 0.07 & 1.04 & 2.04 & 0.086 & 0.402 & 19.97 \\
\hline \multirow[t]{2}{*}{$8 / 31 / 2004$} & Std. Dev. & 0.002 & 0.005 & 0.016 & 0.001 & 0.001 & 0.019 \\
\hline & $\%$ COV & 2.8 & 0.5 & 0.8 & 1.2 & 0.1 & 0.1 \\
\hline Soy 1 B20 & Mean & 0.06 & 0.86 & 2.16 & 0.061 & 0.414 & 19.87 \\
\hline \multirow[t]{2}{*}{$8 / 31 / 2004$} & Std. Dev. & 0.000 & 0.009 & 0.012 & 0.002 & 0.001 & 0.027 \\
\hline & $\%$ COV & 0.6 & 1.0 & 0.6 & 3.0 & 0.2 & 0.1 \\
\hline Baseline & Mean & 0.07 & 1.03 & 2.06 & 0.083 & 0.405 & 19.96 \\
\hline \multirow[t]{2}{*}{$9 / 1 / 2004$} & Std. Dev. & - & - & - & - & - & - \\
\hline & $\%$ COV & - & - & - & - & - & - \\
\hline Soy 2 B20 & Mean & 0.07 & 0.91 & 2.14 & 0.061 & 0.411 & 19.91 \\
\hline \multirow[t]{2}{*}{ 9/1/2004 } & Std. Dev. & 0.001 & 0.019 & 0.025 & 0.002 & 0.000 & 0.008 \\
\hline & $\%$ COV & 1.5 & 2.1 & 1.2 & 2.8 & 0.1 & 0.0 \\
\hline Baseline & Mean & 0.06 & 1.02 & 2.09 & 0.086 & 0.403 & 19.88 \\
\hline \multirow[t]{2}{*}{ 9/9/2004 } & Std. Dev. & 0.002 & 0.011 & 0.017 & 0.001 & 0.000 & 0.107 \\
\hline & $\%$ COV & 3.6 & 1.1 & 0.8 & 0.8 & 0.1 & 0.5 \\
\hline Soy 2 B20 & Mean & 0.06 & 0.91 & 2.20 & 0.064 & 0.413 & 19.84 \\
\hline \multirow[t]{2}{*}{ 9/9/2004 } & Std. Dev. & 0.001 & 0.007 & 0.007 & 0.002 & 0.001 & 0.106 \\
\hline & $\%$ COV & 1.2 & 0.7 & 0.3 & 3.5 & 0.2 & 0.5 \\
\hline Baseline & Mean & 0.07 & 1.04 & 2.06 & 0.083 & 0.402 & 20.00 \\
\hline \multirow[t]{2}{*}{$9 / 2 / 2004$} & Std. Dev. & 0.002 & 0.017 & 0.033 & 0.002 & 0.001 & 0.005 \\
\hline & $\%$ COV & 2.8 & 1.6 & 1.6 & 2.5 & 0.1 & 0.0 \\
\hline Canola B20 & Mean & 0.07 & 0.93 & 2.13 & 0.066 & 0.411 & 19.93 \\
\hline \multirow[t]{2}{*}{ 9/2/2004 } & Std. Dev. & 0.001 & 0.013 & 0.013 & 0.001 & 0.000 & 0.024 \\
\hline & $\%$ COV & 1.6 & 1.4 & 0.6 & 1.6 & 0.1 & 0.1 \\
\hline
\end{tabular}


Table A-3. Continued.

\begin{tabular}{|c|c|c|c|c|c|c|c|}
\hline \multirow[b]{2}{*}{ Fuel } & & \multicolumn{4}{|c|}{ Transient Emissions, g/hp-hr } & \multirow{2}{*}{$\begin{array}{c}\text { BSFC } \\
\text { lb/hp-hr }\end{array}$} & \multirow{2}{*}{$\begin{array}{l}\text { Work } \\
\text { hp-hr }\end{array}$} \\
\hline & & $\mathrm{HC}$ & CO & NOx & PM & & \\
\hline Baseline & Mean & 0.07 & 1.06 & 2.04 & 0.085 & 0.403 & 19.98 \\
\hline \multirow[t]{2}{*}{$9 / 3 / 2004$} & Std. Dev. & 0.001 & 0.017 & 0.011 & 0.000 & 0.001 & 0.021 \\
\hline & $\%$ COV & 1.6 & 1.6 & 0.5 & 0.1 & 0.2 & 0.1 \\
\hline Tallow B20 & Mean & 0.06 & 0.93 & 2.13 & 0.067 & 0.413 & 19.88 \\
\hline \multirow[t]{2}{*}{$9 / 3 / 2004$} & Std. Dev. & 0.001 & 0.012 & 0.016 & 0.002 & 0.000 & 0.015 \\
\hline & $\%$ COV & 0.8 & 1.2 & 0.7 & 2.7 & 0.0 & 0.1 \\
\hline Baseline & Mean & 0.07 & 1.02 & 2.07 & 0.082 & 0.402 & 20.00 \\
\hline \multirow[t]{2}{*}{ 9/7/2004 } & Std. Dev. & 0.002 & 0.005 & 0.007 & 0.001 & 0.000 & 0.014 \\
\hline & $\%$ COV & 2.9 & 0.5 & 0.3 & 1.1 & 0.1 & 0.1 \\
\hline YG B20 & Mean & 0.06 & 0.87 & 2.12 & 0.064 & 0.411 & 19.95 \\
\hline \multirow[t]{2}{*}{$9 / 7 / 2004$} & Std. Dev. & 0.001 & 0.010 & 0.018 & 0.002 & 0.001 & 0.009 \\
\hline & $\%$ COV & 1.4 & 1.2 & 0.9 & 2.6 & 0.1 & 0.0 \\
\hline Baseline & Mean & 0.07 & 1.01 & 2.11 & 0.080 & 0.404 & 19.98 \\
\hline \multirow[t]{2}{*}{$9 / 14 / 2004$} & Std. Dev. & 0.004 & 0.049 & 0.024 & 0.003 & 0.002 & 0.025 \\
\hline & $\%$ COV & 4.8 & 4.9 & 1.1 & 3.3 & 0.4 & 0.1 \\
\hline Soy 2 B10 & Mean & 0.07 & 0.98 & 2.17 & 0.071 & 0.408 & 19.92 \\
\hline \multirow[t]{2}{*}{$9 / 14 / 2004$} & Std. Dev. & 0.001 & 0.013 & 0.010 & 0.001 & 0.000 & 0.004 \\
\hline & $\%$ COV & 1.8 & 1.3 & 0.5 & 2.0 & 0.0 & 0.0 \\
\hline Soy 2 B100 & Mean & 0.05 & 0.63 & 2.75 & 0.020 & 0.459 & 19.39 \\
\hline \multirow[t]{2}{*}{ 9/14/2004 } & Std. Dev. & 0.000 & 0.012 & 0.021 & 0.001 & 0.000 & 0.042 \\
\hline & $\%$ COV & 0.1 & 1.9 & 0.8 & 7.1 & 0.0 & 0.2 \\
\hline Baseline & Mean & 0.070 & 0.96 & 2.13 & 0.079 & 0.404 & 19.99 \\
\hline \multirow[t]{2}{*}{$9 / 15 / 2004$} & Std. Dev. & 0.001 & 0.010 & 0.013 & 0.001 & 0.001 & 0.035 \\
\hline & $\%$ COV & 1.8 & 1.0 & 0.61 & 1.8 & 0.31 & 0.18 \\
\hline Soy 2 B50 & Mean & 0.06 & 0.75 & 2.37 & 0.042 & 0.430 & 19.76 \\
\hline \multirow[t]{2}{*}{$9 / 15 / 2004$} & Std. Dev. & 0.003 & 0.014 & 0.027 & 0.001 & 0.001 & 0.022 \\
\hline & $\%$ COV & 5.1 & 1.9 & 1.1 & 3.4 & 0.2 & 0.1 \\
\hline Soy 2 B20 & Mean & 0.07 & 0.85 & 2.25 & 0.062 & 0.415 & 19.91 \\
\hline \multirow[t]{2}{*}{$9 / 15 / 2004$} & Std. Dev. & 0.002 & 0.022 & 0.050 & 0.000 & 0.001 & 0.023 \\
\hline & $\%$ COV & 3.1 & 2.5 & 2.2 & 0.1 & 0.2 & 0.1 \\
\hline Baseline & Mean & 0.07 & 1.01 & 2.04 & 0.087 & 0.406 & 20.02 \\
\hline \multirow[t]{2}{*}{$9 / 31 / 2004$} & Std. Dev. & 0.003 & 0.011 & 0.009 & 0.001 & 0.001 & 0.025 \\
\hline & $\%$ COV & 4.3 & 1.1 & 0.4 & 1.2 & 0.2 & 0.1 \\
\hline Soy 2 B20+EHN ${ }^{1}$ & Mean & 0.06 & 0.84 & 2.21 & 0.069 & 0.417 & 19.93 \\
\hline \multirow[t]{2}{*}{$9 / 31 / 2004$} & Std. Dev. & 0.001 & 0.015 & 0.015 & 0.003 & 0.001 & 0.015 \\
\hline & $\%$ COV & 1.7 & 1.8 & 0.7 & 4.4 & 0.2 & 0.08 \\
\hline
\end{tabular}

\footnotetext{
Soy B20 plus 4000 ppm of 2-ethyl hexyl nitrate
} 
Table A-4. Hot-Start Transient Emission Test Results for the DDC Series 60 Engine $(1 \mathrm{~g} / \mathrm{bhp}-\mathrm{h}=1.341 \mathrm{~kW}-\mathrm{h})$.

\begin{tabular}{|c|c|c|c|c|c|c|c|}
\hline \multirow{2}{*}{ Fuel } & & \multicolumn{4}{|c|}{ Transient Emissions, g/hp-hr } & \multirow{2}{*}{$\frac{\text { BSFC }}{\text { lb/hp-hr }}$} & \multirow{2}{*}{$\begin{array}{l}\text { Work } \\
\text { hp-hr }\end{array}$} \\
\hline & & HC & CO & NOx & PM & & \\
\hline \multirow{3}{*}{$\begin{array}{l}\text { Baseline } \\
8 / 25 / 2004\end{array}$} & Mean & 0.07 & 0.53 & 2.16 & 0.097 & 0.404 & 33.23 \\
\hline & Std. Dev. & 0.001 & 0.010 & 0.039 & 0.0011 & 0.0062 & 0.056 \\
\hline & $\%$ COV & 1.5 & 1.9 & 1.8 & 1.1 & 1.5 & 0.2 \\
\hline \multirow{3}{*}{$\begin{array}{l}\text { Soy B20 } \\
8 / 25 / 2004\end{array}$} & Mean & 0.07 & 0.51 & 2.24 & 0.072 & 0.416 & 33.12 \\
\hline & Std. Dev. & 0.006 & 0.011 & 0.042 & 0.0012 & 0.0059 & 0.040 \\
\hline & $\% \mathrm{COV}$ & 8.3 & 2.1 & 1.9 & 1.7 & 1.4 & 0.1 \\
\hline \multirow{3}{*}{$\begin{array}{l}\text { Baseline } \\
8 / 26 / 2004\end{array}$} & Mean & 0.06 & 0.49 & 2.13 & 0.095 & 0.402 & 33.11 \\
\hline & Std. Dev. & 0.006 & 0.020 & 0.091 & 0.0013 & 0.0052 & 0.036 \\
\hline & $\%$ COV & 10.5 & 4.0 & 4.3 & 1.3 & 1.3 & 0.1 \\
\hline YG B20 & Mean & 0.06 & 0.49 & 2.10 & 0.073 & 0.418 & 33.14 \\
\hline \multirow[t]{2}{*}{$8 / 26 / 2004$} & Std. Dev. & 0.011 & 0.011 & 0.036 & 0.0012 & 0.0040 & 0.178 \\
\hline & $\%$ COV & 19.2 & 2.2 & 1.7 & 1.7 & 1.0 & 0.5 \\
\hline \multirow{3}{*}{$\begin{array}{l}\text { Baseline } \\
8 / 27 / 2004\end{array}$} & Mean & 0.06 & 0.53 & 2.12 & 0.096 & 0.407 & 33.25 \\
\hline & Std. Dev. & 0.001 & 0.020 & 0.006 & 0.0024 & 0.0021 & 0.046 \\
\hline & $\%$ COV & 1.0 & 3.8 & 0.3 & 2.5 & 0.5 & 0.1 \\
\hline \multirow{3}{*}{$\begin{array}{l}\text { Tallow B20 } \\
8 / 27 / 2004\end{array}$} & Mean & 0.06 & 0.50 & 2.15 & 0.073 & 0.421 & 33.05 \\
\hline & Std. Dev. & 0.003 & 0.010 & 0.022 & 0.0003 & 0.0035 & 0.010 \\
\hline & $\%$ COV & 4.9 & 2.1 & 1.0 & 0.5 & 0.8 & 0.0 \\
\hline \multirow{3}{*}{$\begin{array}{l}\text { Baseline } \\
8 / 29 / 2004\end{array}$} & Mean & 0.07 & 0.50 & 2.11 & 0.093 & 0.409 & 33.12 \\
\hline & Std. Dev. & 0.010 & 0.001 & 0.020 & 0.0007 & 0.0009 & 0.044 \\
\hline & $\%$ COV & 14.4 & 0.2 & 0.9 & 0.8 & 0.2 & 0.1 \\
\hline \multirow{3}{*}{$\begin{array}{l}\text { Soy B20+EHN }{ }^{1} \\
8 / 30 / 2004\end{array}$} & Mean & 0.05 & 0.41 & 2.24 & 0.074 & 0.420 & 33.03 \\
\hline & Std. Dev. & 0.002 & 0.009 & 0.012 & 0.0008 & 0.0057 & 0.035 \\
\hline & $\%$ COV & 4.7 & 2.2 & 0.5 & 1.1 & 1.4 & 0.1 \\
\hline \multirow{3}{*}{$\begin{array}{l}\text { Baseline } \\
8 / 31 / 2004\end{array}$} & Mean & 0.05 & 0.50 & 2.09 & 0.095 & 0.412 & 33.19 \\
\hline & Std. Dev. & 0.006 & 0.008 & 0.049 & 0.0014 & 0.0017 & 0.007 \\
\hline & $\%$ COV & 11.0 & 1.7 & 2.3 & 1.5 & 0.4 & 0.0 \\
\hline \multirow{3}{*}{$\begin{array}{l}\text { Baseline } \\
9 / 2 / 2004\end{array}$} & Mean & 0.06 & 0.48 & 2.07 & 0.093 & 0.406 & 33.17 \\
\hline & Std. Dev. & 0.007 & 0.012 & 0.039 & 0.0016 & 0.0063 & 0.040 \\
\hline & $\%$ COV & 12.4 & 2.4 & 1.9 & 1.7 & 1.5 & 0.1 \\
\hline \multirow{3}{*}{$\begin{array}{l}\text { Soy+Tallow } \\
\text { B20 } \\
9 / 2 / 2004\end{array}$} & Mean & 0.05 & 0.45 & 2.18 & 0.070 & 0.417 & 33.05 \\
\hline & Std. Dev. & 0.005 & 0.008 & 0.061 & 0.0001 & 0.0034 & 0.026 \\
\hline & $\%$ COV & 12.0 & 1.8 & 2.8 & 0.2 & 0.8 & 0.1 \\
\hline \multicolumn{2}{|c|}{ Overall Baseline Mean } & 0.06 & 0.50 & 2.12 & 0.095 & 0.406 & 33.17 \\
\hline \multirow{2}{*}{\multicolumn{2}{|c|}{$\begin{array}{l}\text { Overall Baseline Std. Dev. } \\
\text { Overall Baseline \% COV }\end{array}$}} & 0.010 & 0.024 & 0.048 & 0.0020 & 0.0047 & 0.067 \\
\hline & & 15.8 & 4.8 & 2.2 & 2.2 & 1.2 & 0.2 \\
\hline
\end{tabular}

${ }^{1}$ Soy B20 plus 5000 ppm of 2-ethyl hexyl nitrate

${ }^{2} \mathrm{~B} 20$ prepared from $80 \%$ baseline, $10 \%$ soy biodiesel and $10 \%$ tallow biodiesel 